\title{
Impacts of Climate Change to Poultry Production in Africa: Adaptation Options for Broiler Chickens
}

\author{
M. O. Abioja and J. A. Abiona
}

\section{Contents}

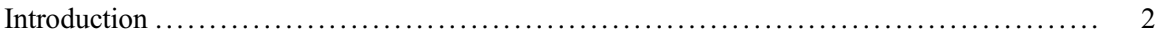

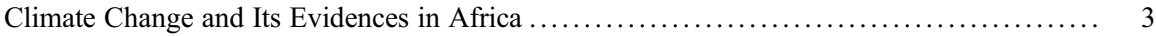

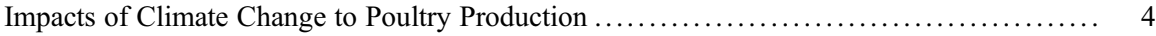

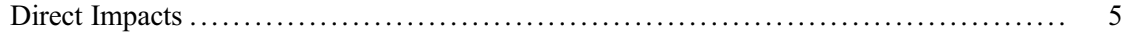

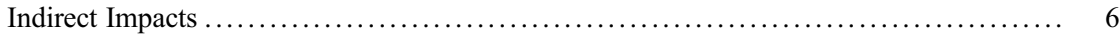

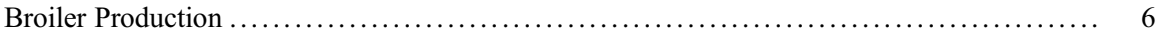

Heat Stress and Broiler Chickens ......................................... 7

Negative Effects of Heat Stress in Broiler Chickens ............................. 8

Adaptation Options to Climate Change for Broiler Chickens $\ldots \ldots \ldots \ldots \ldots \ldots \ldots \ldots \ldots \ldots \ldots, \quad 9$

Housing System and Climate Amelioration .................................... 9

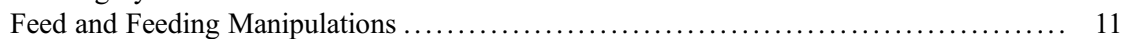

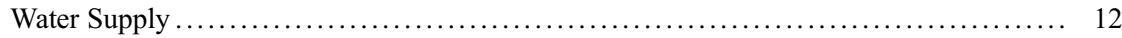

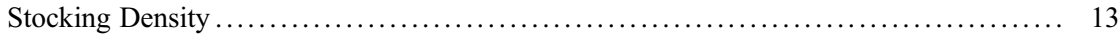

Epigenetic Adaptation to Thermal Assaults ................................... 14

Use of Honey and Other Natural Phytochemicals .............................. 15

This chapter was previously published non-open access with exclusive rights reserved by the Publisher. It has been changed retrospectively to open access under a CC BY 4.0 license and the copyright holder is "The Author(s)". For further details, please see the license information at the end of the chapter.

Electronic supplementary material: The online version of this chapter (https://doi.org/10.1007/ 978-3-030-42091-8_111-2) contains supplementary material, which is available to authorized users.

M. O. Abioja $(\varangle) \cdot$ J. A. Abiona

Department of Animal Physiology, College of Animal Science and Livestock Production, Federal University of Agriculture, Abeokuta, Nigeria

e-mail: abiojamo@funaab.edu.ng; abionaja@funaab.edu.ng 
Breeding for Thermotolerant Strains in Africa ................................ 17

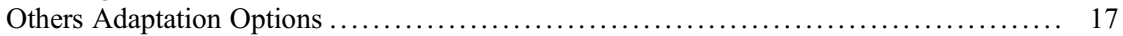

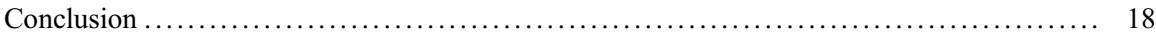

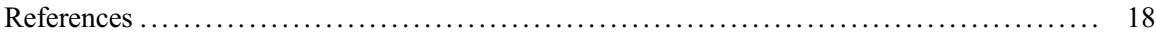

\section{Abstract}

Global climate change poses a great threat to poultry production. Greenhouse gases (GHGs) are released through both natural and anthropogenic sources into the atmosphere. Though poultry production contributes little to the release of GHGs, the subsector has been shown to be greatly affected by climate change and global warming. Poultry production as a major subsector of agriculture has provided the teeming population with a supply of needed animal protein in terms of meat and egg production all over the world. It is yet a major global employer of labor. Though it occupies a vantage position in meeting human needs, it is being threatened by climate change, especially in Africa where necessary structure to tackle the menace is nonexistent. Broiler chickens that are reared mainly for chicken meat cannot tolerate the high ambient temperature that prevails mostly in the tropical environment. Chickens are homeotherms that homeostatically regulate core body temperature within a narrow range. Elevated ambient temperature above thermal comfort zone, such as envisaged in climate change scenarios, will trigger series of neuroendocrine modulations that are detrimental to the welfare and productivity in broiler chickens. Such birds are said to be undergoing heat stress (HS). Negative effects of HS include reduced feed consumption, growth rate, feed digestion and efficiency, immunity, welfare, and survivability. Various adaptive measures that could be harnessed by broiler farmers, ranging from housing, feeding, watering, stocking, breeding for thermotolerant strains, thermal conditioning, use of phytochemicals, and much more, are reviewed upon in this chapter.

\section{Keywords}

Acclimation - Acclimatization - Broiler chickens · Environmental temperature Heat stress $\cdot$ Thermal comfort zone $\cdot$ Thermoregulation

\section{Introduction}

Climate change is defined by Ngaira (2007) as deviations in the patterns of climate over a long period of time while the Intergovernmental Panel on Climate Change (IPCC) recognized it as a change in the state of the climate that can be identified (using statistical tests) by changes in average and standard deviation, and that persists for a long period of time, typically more than one decade or longer (IPCC 2007). It poses a great threat to agricultural and socioeconomic development (Niang et al. 2014). The problem of climate change will add to the burden of heat stress (HS) usually experienced in the tropical regions of Africa because of the predicted increase in global temperature. Though Africa contributes the least 
of the global GHG emission, yet evidences had shown that most developing countries in Africa would be the most affected because of low infrastructural capacity to cope. This is also hinged on the fact of widespread poverty, prevailing slash-and-burn agriculture, erosion, and burning of firewood and farm residues. The problem of desert encroachment and deforestation is also a contributory factor to climate change. All facets of human life will be affected by climate change. Poultry production, a subsector of agriculture that had helped in supplying the needed human protein requirements from chicken, turkey, duck, guinea fowl, geese, and ostrich is not spared. Productivity and welfare of poultry species in Africa will be negatively impacted upon by climate change. Chicken being the most populous and important among poultry species will be most impacted upon. Global chicken population was over 22 billion in 2017. Broiler chickens, raised mainly for meat production with high feed-to-meat conversion efficiency, is the most sensitive to the effects of elevated temperature in the environment among other strains of chickens. Its productivity is grossly affected once the required environmental conditions, especially temperature, are compromised. These necessitate the development of a review of all available options for adaptation of broiler production to the prevailing and envisaged global warming.

\section{Climate Change and Its Evidences in Africa}

Livestock subsector was viewed as a victim until it was implicated as a major contributor to global emission of greenhouse gases (GHGs) such as $\mathrm{CO}_{2}$ and $\mathrm{CH}_{4}$. FAO's report Livestock's Long Shadow opened up the minds of many stakeholders to this fact (FAO 2006) that the subsector contributes 18\% of global GHGs. These gases cause warming of the globe by entrapping heat on the earth crust not allowing it to be reflected to the atmosphere. Resultant global warming and climatic variability have been reported to have both direct and indirect impacts on livestock production, including reduced growth and reproductive efficiency, low quality and quantity of feed materials, and increased prevalence of disease due to rise in temperature (Renaudeau et al. 2012). Africa is the most threatened all over the world with predicted effects of climate change (Ngaira 2007). Though, the continent is the least emitter of these GHGs of all continents, unlike other industrialized nations that are emitting these in tonnes daily.

Predicted temperature rise of $2-6^{\circ} \mathrm{C}$ is expected over the land of Africa within the next 100 years and a rise of $1.5-3.0^{\circ} \mathrm{C}$ by 2050 . This is much more severe than experienced in other regions. The presence of climate change in Africa is evident in that the three warmest years over African land since 1950 had been identified as 2010, 2016, and 2017, all occurring within the last decade. Average deviation from the mean temperature of $1961-1990$ was $+1.41,+1.26$, and $+1.20^{\circ} \mathrm{C}$, respectively. The warming rate per century recorded in Africa $\left(+3.7^{\circ} \mathrm{C}\right)$ is an alarming signal. ACMAD (2017) stated that temperature anomalies varied over the different subregions of Africa in 2017. Northern Africa experienced the average temperature 
anomaly was $1.1^{\circ} \mathrm{C}$ warmer than the long-term mean. Similar to the experience in the North Africa, 2017 had temperature anomaly of $1.2{ }^{\circ} \mathrm{C}$ above average over the West African region. Central Africa had a temperature anomaly of $1.3{ }^{\circ} \mathrm{C}$ above average. Over Eastern Africa land, $1.2{ }^{\circ} \mathrm{C}$ was recorded above average while anomaly of $1.0{ }^{\circ} \mathrm{C}$ above average was reported over the Southern Africa region in 2017. However, temperatures in 2017 were mild over the island countries in the Indian Ocean. For instance, one of the coldest years in Madagascar is 2017, with temperature deviation of $0.3{ }^{\circ} \mathrm{C}$ below the mean. Climate change will pose considerable risks to the livelihood of the dwellers of most countries in Africa that mainly depend on agriculture (Hummel 2015).

Poultry farmers in Africa are aware of climate change because many of them have been taken cognizance of variability in rainfall amount and pattern, heat spells, and variability in other climatic elements. Indigenous technical knowledge and systems that had been explored by farmers in adapting to high environmental temperature abounds.

\section{Impacts of Climate Change to Poultry Production}

In Africa, there are two main poultry production systems. Distinguishing factors between the two are associated with the scale of production, stock, management system, and productivity. The two systems are the commercial poultry and the rural poultry. The former is on large to medium scale, stocking improved/exotic breeds, reared intensively with adequate care for feeding, health, and welfare of the birds in modern facilities in large number. In terms of productivity, the commercial gives higher returns. On the other hand, the latter, also known as village or backyard poultry, is usually on small scale, stocking the locally adapted indigenous breeds of birds. The productivity is lower with the village poultry system. In history, the latter is far older than the former. Meanwhile, intermediate system between the two systems has evolved over time. Commercial poultry system includes breeding farms where grandparent (GP) and parent stocks are raised. Day-old chicks (broiler and layer lines) are produced by the breeding farms. Commercial broiler farms raise the chicks till table size of around $2.5 \mathrm{~kg}$ in $6-8$ weeks. The effort to genetically improve commercial stocks of broiler chickens began in earnest in the USA in the 1940s (FAO 2020). And since then, it has been the stories of great leaps in improvement of growth rate and feed conversion efficiency. The successful breeding company started exporting chicken hybrids with improved strains into African countries in the 1950s. This coincided with the rapid development of commercial poultry systems in Africa.

All these systems are under the threats of the climate change but the most affected of them is the commercial poultry system. Impacts of climate change on poultry production (Fig. 1) could be categorized into two. 


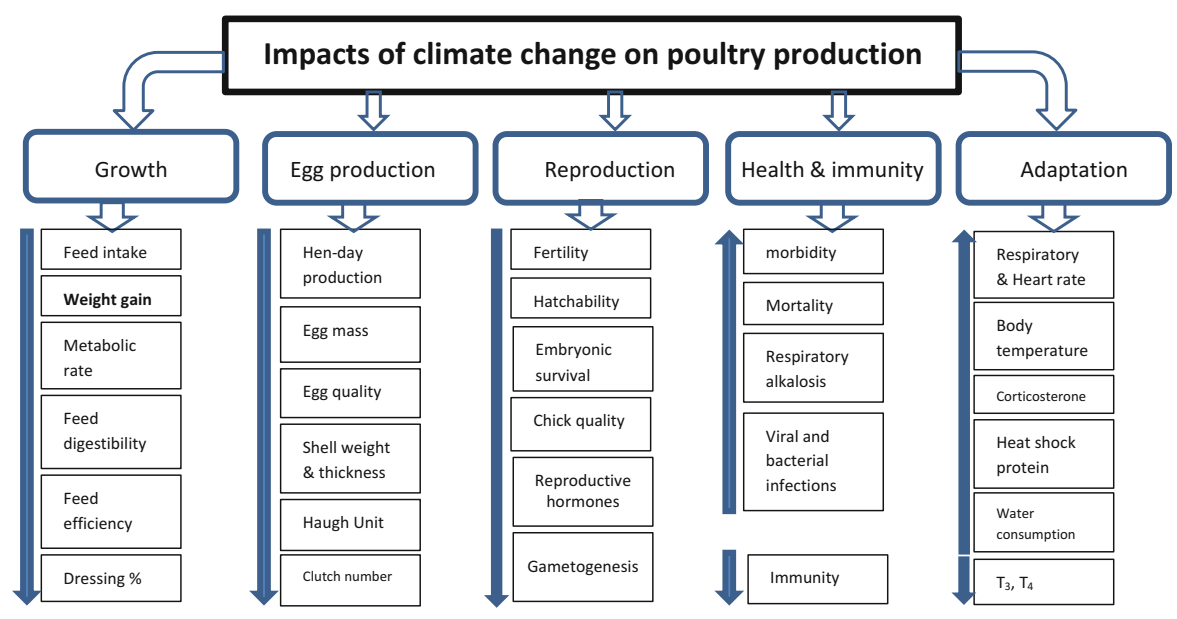

Fig. 1 Diagram illustration the effects of climate change on poultry production

\section{Direct Impacts}

Climate change has impacts on poultry production by way of imposing stress on the homeostasis in the birds. It may come in the form of extreme climatic situations: elevated temperature, flood or drought, and water scarcity (Tiruneh and Tegene 2018). Common among these is increased global temperature. Extreme weather conditions lead to production losses (reduced growth rate, lowered egg hen-day production, and increased morbidity and mortality) in poultry birds (Attia et al. 2011). Poultry birds can adapt to hot environment. However, the mechanisms of coping subject the birds to losses and diversion of nutrients meant for production to thermoregulation.

Growth performance of the birds is grossly affected by perturbations in weather conditions in the surroundings. The most important of these is the pen temperature. Changes in humidity work synergistically with high environmental temperature to impact negatively on poultry birds. In hot environment, feed consumption is reduced in order to limit metabolic heat production. Available nutrients in the system are utilized for heat loss mechanisms instead of profitable usage for muscle accretion. Digesta mobility in the gastrointestinal tract (GIT) is drastically reduced and efficiency of nutrient digestion and assimilation in the intestines is lowered. Histomorphometric studies show that the epithelial cells of the intestines are affected by HS (Santos et al. 2015). Vasodilation of blood vessels at the periphery reduces blood flow across GIT of the birds thereby lowering the efficiency of digestion and nutrient uptake. All these factors cumulatively contributed to the lowered final liveweight and dressing percentage usually obtained in heat-stressed chickens (Syafwan et al. 2011).

Productivity in laying chickens is negatively affected by elevation in temperature by reducing the number and size of eggs produced. Internal and external quality traits of the eggs are compromised by changes in weather conditions around the birds. High ambient temperature lowers egg fertility, hatchability, and chick quality 
in breeder stocks (Ayo et al. 2011). Impact of climate change will be felt on the synthesis and the release of reproductive hormones (FSH, LH, progesterone, estrogen, and testosterone) with resultant reduction in efficiency of gametogenesis in male (spermatogenesis; Al-Saffar and Rose 2002; Karaca et al. 2002) and female (oogenesis) birds (Rozenboim et al. 2007). Heat-stressed cocks produce semen with low sperm concentration and quality. Immunity of the birds is lowered under HS conditions (Calefi et al. 2017).

\section{Indirect Impacts}

Indirectly, climate change will impact on feed ingredient availability and quality for the poultry birds; availability of adequate good quality water; and pest and diseases infestation in Africa. Climate has effects on the yield and quality of produce of crop husbandry from where most of the feed ingredients are sourced. Feed ingredients such as maize, groundnut cake, cotton-seed cake, wheat offal, and rice bran are gotten from agronomic activities. Semiarid regions experiencing low rainfall amount and irregular pattern cannot boast of bountiful harvest. This may trigger skyrocketing of the feed price for poultry species and exacerbate the animal-human competition for feed materials except irrigation systems are employed. Rain-fed cropping in the forest vegetation will also be affected by high temperature and insufficient rainfall.

Availability of adequate good quality water is essential to productivity in poultry production. Climate change has reared up its head in reduction in water in the ponds, streams, rivers, and the seas immediately after rainy season all around Africa because of increased rate of evaporation (Alemayehu and Woldeamlak 2017). Water shortage adversely affects body weight and lymphoid organs (Mustafa et al. 2010). Changes in the existing pattern of pest and disease infestations are envisaged under different climatic change scenarios. This will affect productivity of poultry in terms of morbidity, mortality, and the cost of vaccinations and medications.

\section{Broiler Production}

Broiler chickens are reared mainly for meat production. The production cycle lasts for 5 to 8 weeks, with high rate of turn-over of feed to meat from day-old chicks to market age. Chicks are obtained from specialized lines called breeder chickens. At market age, the liveweight of 40-55 $\mathrm{g}$ at day-old would have multiplied by 50 times to give about $2.5 \mathrm{~kg}$ chickens. Both male and female sexes of broiler chickens are reared for meat, though male chickens grow faster than the female counterparts. Most of the strains of broiler chickens reared in Africa are developed in the temperate regions of the world such as the USA and the Netherlands but are imported into Africa. The birds are incapable of expressing the inherent growth potentials because of HS and the productivity is often below what is obtainable in their counterparts in the cooler climes. Broiler chickens are sensitive to elevation in ambient temperature during growing phase. Production and demand for chicken meat has increased tremendously 
worldwide over the last few decades. This results from different selection and crossbreeding techniques that are employed to improve growth rate of broiler chickens, reaching market weight within a short span of time than what is obtained in the past. To continue enjoying the gains of several years of broiler development, efforts toward ensuring adaptation of broiler chickens to prevailing high environmental temperature expected in climate change are worthwhile.

\section{Heat Stress and Broiler Chickens}

All farm animals in the tropical region suffer from HS at one time or the other because of constant elevated ambient temperature (Altan et al. 2000). People and livestock in the temperate regions are exposed to HS induced by elevated environmental temperature during summer. HS is an adaptive response that occurs in a bird when the rate of thermolysis is below thermogenesis and the ability to lose body heat exceeded by the heat load acquired through exposure to high ambient temperature (Al-Saffar and Rose 2002).

Broiler chickens are homeothermic animals capable of maintaining the body temperature within a narrow range irrespective of the environmental temperature. They possess an internal homeostatic mechanism that regulates internal body temperature. The internal body temperature of adult chicken is normally between $41.2{ }^{\circ} \mathrm{C}$ and $42.2{ }^{\circ} \mathrm{C}$ (Mitchell et al. 2005). Newly hatched birds have a body temperature approximately $2-3{ }^{\circ} \mathrm{C}$ below that of the adult birds. Additional source of warmth is needed by the chicks during the first 21 days post-hatch to maintain body temperature for normal growth and development. However, as the birds increase in age and size, their requirement for supplemental heat declines. This results from the development of insulating feathers, higher metabolic heat production, and maturation of the thermoregulatory system of the birds. In general, the thermal comfort or thermoneural zone (TNZ) for broilers declines from about $32{ }^{\circ} \mathrm{C}$ at hatching to around $24{ }^{\circ} \mathrm{C}$ at 3 to 4 weeks of age and to about $21.1{ }^{\circ} \mathrm{C}$ thereafter. The birds at this period are capable of heat regulation to maintain core body temperature. As temperature increases beyond $21.1{ }^{\circ} \mathrm{C}$ around adult chickens, mechanisms for heat loss are triggered.

The fast-growing broiler lines are susceptible to high temperature mostly during growing-finishing phase. The high susceptibility to HS results from resultant inferior development of their cardiovascular and respiratory systems (Yahav 2000). As well, chickens do not possess sweat glands (Mitchell et al. 2005). In addition, their rapid growth rate is supported by high feed intake, thus, as they grow, metabolic heat production increases but their heat dissipation capacity does not. Broiler chickens gain heat from metabolism, physical activity, and environment. This heat load must be dissipated to maintain constant body temperature. Metabolic heat production in broilers is particularly high because of their high feed intake compared to other strains of chickens. Their growth rate is supported by feed consumption which leads to generation of heat in the body system. Increased heat production does not have any adverse consequence on the birds in TNZ and cold environments. But as 
Fig. 2 Diagram showing broiler chicken exhibiting panting behaviour

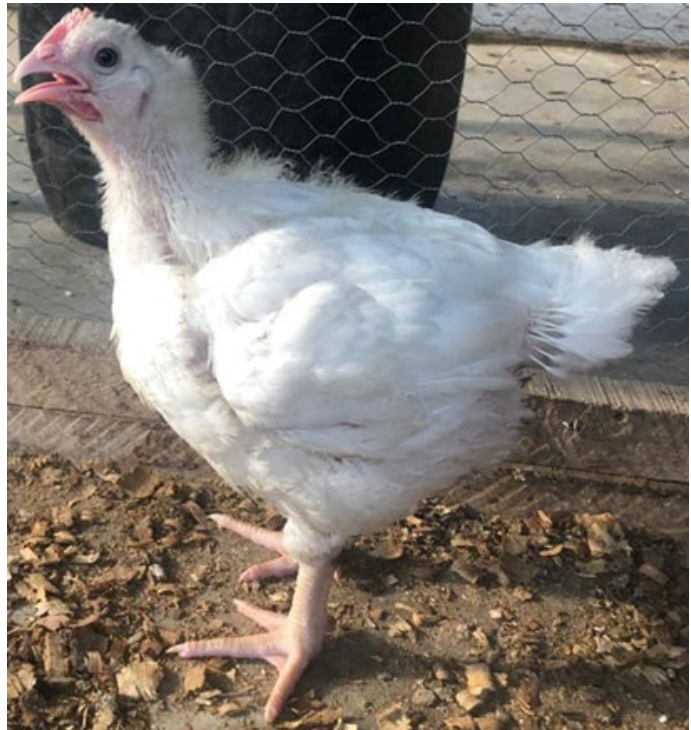

ambient temperature overshoots the upper limit of the TNZ, the ability of the bird to dissipate heat is compromised making excessive heat production built-up. The condition leads to hyperthermia (increased core body temperature) which is potentially life threatening. Before this stage, the body temperature is regulated mainly by loss of heat to outside environment through conduction, convection, and radiation, also known as non-evaporative heat loss. Effectiveness of these three means of heat loss is limited to lower temperatures (Borges et al. 2003).

As the temperature peaks, chickens exhibit panting, an evaporative heat loss behavior (Fig. 2; Video 1). Panting involves evaporative cooling of the bird by losing heat from the respiratory tract. They also display wing-raising to expose the poorly feathered sides of the body and under-wing area. Sometimes, they dig into the litter to sit on a cooler floor in the pen during hot periods. Panting occurs when the deep body temperature of poultry reaches $42{ }^{\circ} \mathrm{C}$. Respiratory rate may increase from 25 to 150 breaths per minute over a 20 -min period in response to an increase in ambient temperature from TNZ. In a healthy chicken, hyperventilation through panting will remove approximately $0.54 \mathrm{Kcal} / \mathrm{g}$ water lost in the lungs. Chickens increase saliva secretion during this period because of the need to the surface of the respiratory tract wet during panting.

\section{Negative Effects of Heat Stress in Broiler Chickens}

The adverse effects of HS can be seen in decreased feed consumption, increased water intake, rise in body temperature, respiratory rate, heart rate, electrolyte imbalance, changes in hematological parameters, hormone levels and enzymatic activities, 
and perturbations in blood $p H$ (respiratory alkalosis; Lara and Rostagno 2013). All these negatively affect productivity of the animal. An increase in body temperature above the regulated range, because of exposure to hot environmental conditions, may lead to a cascade of irreversible thermoregulatory events that may be lethal for the birds. Generally, broiler chickens try to lower its heat production by reducing its feed consumption during heat episodes. The reduction in feed consumption can be as high as $1.5 \%$ per $1{ }^{\circ} \mathrm{C}$ increase in temperature above TNZ. Reduction in feed consumption consequentially leads to insufficiency of essential nutrients. Coupled with this is the lowered digestibility of feed in the gastrointestinal tract of the birds. Growth rate is therefore reduced in broiler birds when environmental temperature rises because even the little energy obtained from the small feed consumed is expended in panting. The result is that birds had lower final body weight. Chronic HS increases the time to reach market weight and impairs feed digestibility. More feed is required to lay down unit weight of chicken than in TNZ conditions. Exposure to hot weather leads to high mortality in broilers and loss of immunity. Efforts to increase feed consumption during HS by force-feeding have been shown to decrease survival. Mortality in broilers up to $10 \%$ of the total production has been reported during HS. Egg production, fertility, and hatchability are said to be grossly affected in both grandparent and parent (broiler breeder) stocks. Time expected for feeding is expended in panting and beside water troughs. Birds consume more water during $\mathrm{HS}$ exposure. Excessive loss of $\mathrm{CO}_{2}$ in exhaled air during panting results in high blood $p H$, a syndrome called respiratory alkalosis.

\section{Adaptation Options to Climate Change for Broiler Chickens}

\section{Housing System and Climate Amelioration}

Ideal broiler chicken environment must meet the requirement of the birds for adequate pen temperature, relative humidity, and air circulation. Broiler houses are closed system in most industrialized countries where the temperature and humidity are fully controlled, unlike in developing countries where open-sided housing units are common. Foggers, tunnel ventilators, fans, and misters are used to cool the environment in closed systems. However, the cost of installing and maintaining fans, foggers, ventilators, misting pumps, and so on in poultry houses is often beyond what most farmers can afford.

Attaining the optimal range of climatic variables in the open-sided poultry houses common in the tropics is difficult and almost impossible (Abioja 2010). However, proper ventilation is essential in minimizing the effect of heat in African poultry housing units. As the higher environmental temperature is expected all over Africa, the following should be considered for broiler housing:

- Orientation of the housing units should allow for cross-ventilation.

- Low-walled structures completed with wire mesh to ensure cross-ventilation (Fig.

3). High walled structures trap heat inside and will not be applicable. 
- Mud wall houses provide cooler interior than brick wall housing unit.

- Roofing style should be such that allow for proper ventilation.

- Roofing materials must be considered. Asbestos roof is preferred to corrugated iron sheet. Local materials that enable heat transfer such as palm fronds, long grasses such used for thatched roof could be used.

- Tree planting around broiler housing units will provide coolness (Fig. 4).

- The use of mobile pens with wire mesh floor placed under shade of trees.

Broiler chickens are commonly raised on deep-litter floor in most areas of the world, but the use of cage for broiler is becoming common (Shields and Greger

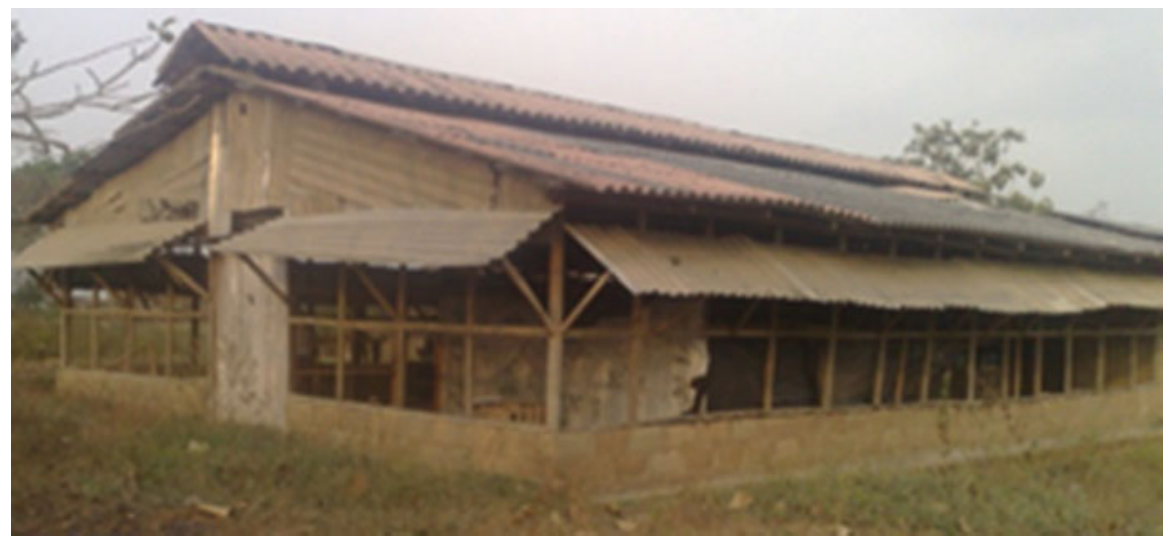

Fig. 3 Low-walled broiler housing units

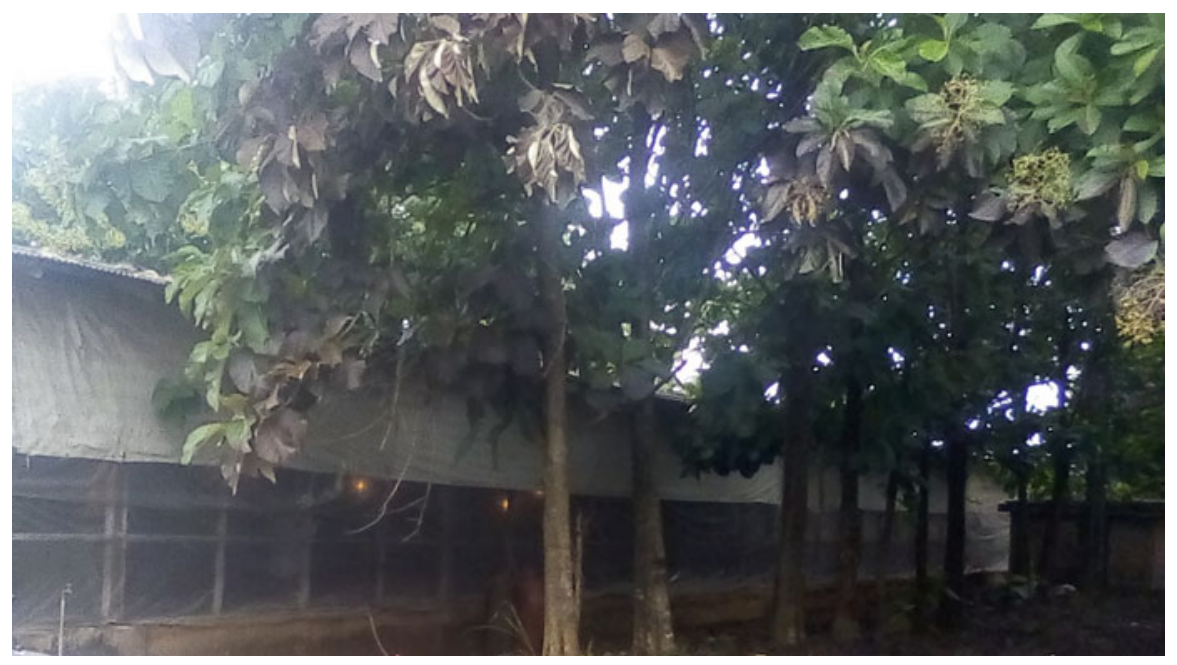

Fig. 4 Tree shade beside broiler housing unit 


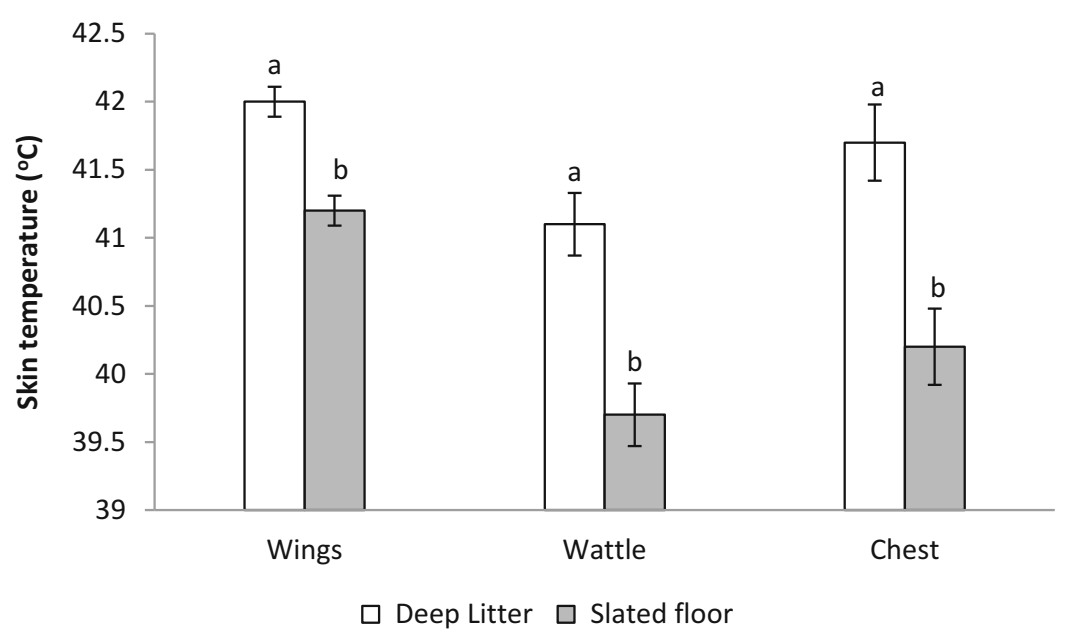

Fig. 5 Effect of floor type on skin temperature of broiler chickens during hot-dry season

Table 1 Effect of floor type on rectal temperature, respiratory rate, heart rate, and skin temperature in broiler chickens during hot season

\begin{tabular}{l|l|c|l}
\hline \multirow{2}{*}{ Parameter } & \multicolumn{2}{|l|}{ Floor } & \multirow{2}{*}{$p$} \\
\cline { 2 - 3 } & Deep-litter & Wire mesh & \\
\hline Rectal temperature, ${ }^{\circ} \mathrm{C}$ & $42.7 \pm 0.07^{\mathrm{a}}$ & $42.0 \pm 0.07^{\mathrm{b}}$ & 0.000 \\
\hline Respiratory rate, breaths $/$ min & $138.8 \pm 2.28^{\mathrm{a}}$ & $125.3 \pm 2.28^{\mathrm{b}}$ & 0.000 \\
\hline Heart rate, beats/min & $198.4 \pm 2.96^{\mathrm{a}}$ & $188.6 \pm 2.96^{\mathrm{b}}$ & 0.023 \\
\hline
\end{tabular}

a, ${ }^{\mathrm{b}}$ Means within the same row with different superscripts differ significantly $(\mathrm{P}<0.05)$

2013). Type of floor has been reported to influence liveweight, feed intake, protein efficiency, and feed conversion ratio in broiler birds reared during winter and summer (Simsek et al. 2014). Wire mesh floor decreased skin temperature, cloacal temperature, respiratory rate, and heart rate of broiler chickens compared to deeplitter floor during hot season (Fig. 5, Table 1; Abioja 2020 -Unpublished data).

\section{Feed and Feeding Manipulations}

Special attention should be given to the nutrition of broiler birds under high temperatures expected under climate change. The major problem of broiler chickens under HS conditions is the fact of reduction in feed consumption. Reduced dietary intake limits available metabolizable energy to sustain normal output. The following suggestions may be of help in feeding broilers during heat spells:

- More energy should be delivered in the form of fat instead of starch (because heat increment from metabolizing fat is lower than that from carbohydrate however rancidity of fat should be given a consideration). 
- Balancing of amino acids in the diet especially methionine and lysine is necessary to augment for deficiencies resulting from low protein intake.

- Diets with low protein level should be recommended in order to reduce heat production in broiler chickens under HS because protein has the highest heat increment of all nutrients.

- Anti-oxidant vitamins (A, C, and E) supplementation has also been credited to improve performance of broilers during HS.

- Wet feeding (Awojobi et al. 2009; Dei and Bumbie 2011) was found to help in improving the final liveweight and weight gain of the birds in a hot climate. Syafwan et al. (2011) stated in a review on HS and feeding strategies in meat-type chickens that wet feeding may be profitable under HS conditions. Feeding wet diets might facilitate an increased water intake. This ensures availability of adequate water for evaporation during panting, hence helping cooling of the bird.

Other areas to be considered for adaptation of broiler chickens to climate change include feeding time (Farghly et al. 2019). Feeding time should be organized in a way that the peak metabolic heat production will not coincide with the highest point in environmental temperature.

\section{Water Supply}

Water is one of the limiting factors in broiler production. It is an essential nutrient that must be taken into consideration if expected productivity is to be achieved. Factors that are of importance in drinking water for chickens include quantity, quality, temperature, salinity, and microbial load. Water supply to the broiler houses must be clean and constant. Broiler chickens consume more water during hot period than in cold climate (Manning et al. 2007; Bruno et al. 2011). Its restriction was reported to raise heterophil-lymphocyte ratio, a major indicator of stress in broiler chickens. Availability of drinkable water during hot spells must be ensured. Water restriction caused reduced weight of lymphoid organs in broiler chickens (Mustafa et al. 2010), which may negatively impact the innate immunity of the birds. In SouthEastern Nigeria located in the rain forest zone, water restriction up to 1.2 liters per day was found to have deleterious effects of the hematological parameters and caused increased activity of liver enzyme which is an indicator of cellular necrosis in broiler chickens (Iheukwumere and Herbert 2003). Water restriction had negative effects on the renal functioning, digestion, immunity, and other vital body systems. Birds subjected to water restriction had an altered behavior, becoming aggressive and irritated. Therefore, water restriction irrespective of the magnitude must not be allowed in broiler production.

Water temperature is another important factor that must be put into right perspective. Warm water is nauseating and not readily acceptable to chickens. Chilled water is preferred to water at ambient temperature. Offering water at low temperature may reduce heat load and respiratory rate in broiler chickens (Table 2). This has been proved to help combat HS in broilers (Abioja et al. 2011, 2013). Practical activity in 
Table 2 Rectal temperature and respiratory rate in broilers offered water of two different temperatures

\begin{tabular}{l|l|l|l}
\hline \multirow{2}{*}{ Parameter } & \multicolumn{2}{|l|}{ Water temperature } & $\begin{array}{l}\text { Standard error of } \\
\text { means }(s e m)\end{array}$ \\
\cline { 2 - 4 } & Ordinary & Low & 0.09 \\
\hline Water temperature $\left({ }^{\circ} \mathrm{C}\right)$ & 30.0 & 16.0 & 0.03 \\
\hline RT at $08.00 \mathrm{~h}\left({ }^{\circ} \mathrm{C}\right)$ & $41.7^{\mathrm{a}}$ & $41.5^{\mathrm{b}}$ & 0.04 \\
\hline RT at $16.00 \mathrm{~h}\left({ }^{\circ} \mathrm{C}\right)$ & $42.5^{\mathrm{a}}$ & $42.1^{\mathrm{b}}$ & 1.13 \\
\hline RR at $08.00 \mathrm{~h}(\mathrm{breaths} / \mathrm{min})$ & $54.0^{\mathrm{a}}$ & $46.7^{\mathrm{b}}$ & 2.11 \\
\hline RR at $16.00 \mathrm{~h}($ breaths $/ \mathrm{min})$ & $85.2^{\mathrm{a}}$ & $62.6^{\mathrm{b}}$ & \\
\hline
\end{tabular}

Abioja MO (Unpublished data)

${ }^{\mathrm{a}, \mathrm{b}}$ Means with differing superscripts within a row were significantly different $(\mathrm{P}<0.05)$

cooling water may involve having water reservoirs placed under shade to disallow overheating by direct sunlight during hot periods. Many poultry managers in all over Africa have been supplying their birds with water cooled with ice cubes during the dry season. The enhanced respiratory rate during HS is critical for body temperature maintenance because of its resultant evaporative cooling.

Specific consequences of the acid-base perturbations have indeed been identified. Electrolytes lost can be replenished with sodium $(\mathrm{Na})$, potassium $(\mathrm{K})$, calcium $(\mathrm{Ca})$, magnesium $(\mathrm{Mg})$, chlorine $(\mathrm{Cl})$, bicarbonate $\left(\mathrm{HCO}_{3}\right)$, and sulfate $\left(\mathrm{SO}_{4}\right)$ salts in water (Ahmad and Sarwar 2006). The addition of the electrolytes to the drinking water not only alters the bird's osmotic balance by replenishing those depleted during HS but also stimulates water consumption and influences water balance. Some African native chickens had been found to have tolerance for water shortage. Chikumba and Chimoyo (2014) reported that Southern African naked neck chickens was found to performed better than Ovambo chickens under conditions of water restriction and would be ideal to raise for meat and egg production in locations where water shortages are a major challenge.

\section{Stocking Density}

Each bird in the flock emits radiant heat to the environment. Low stocking density reduces the number of birds producing heat and the amount of heat that must be removed from the house to maintain temperature. Recommended stocking density appropriate for different housing type should be strictly adhered to. Assuming each bird weigh $2 \mathrm{~kg}$ at slaughter, for controlled environment, the maximum stocking density at slaughter should be $30 \mathrm{~kg} / \mathrm{m}^{2}$; controlled environment during hot period, 24-26 kg/m $\mathrm{m}^{2}$; open-sided house, 20-22 $\mathrm{kg} / \mathrm{m}^{2}$; and open-sided house during hot period, $16-18 \mathrm{~kg} / \mathrm{m}^{2}$. Abudabos et al. (2013) reported that increasing the stocking density rate from 28 to $40 \mathrm{~kg}$ of body weight $/ \mathrm{m}^{2}$ had evident negative effects on the growth performance of broiler chicken. Higher stocking density does jeopardize the well-being of the chickens. 


\section{Epigenetic Adaptation to Thermal Assaults}

Chickens are precocial birds having the development of body functions starting early during the embryonic phase (Nichelmann and Tzschentke 2002). Thermoregulatory mechanisms start during prenatal stage but not fully matured as at pre- and peri-hatch periods (Tzschentke and Basta 2002; Tzschentke et al. 2004). At this point, exposure to a level of stress can trigger an imprinting in chickens. Acute changes in the environmental conditions especially thermal environments induce as a rule, first uncoordinated and immediately nonadaptive reactions. Later, the uncoordinated (immediately) nonadaptive reactions change into coordinated (adaptive) reactions (Tzschentke 2007). Stress is usually avoided because of its perceived repercussions on living tissues. However, evidences are emanating from various research works that exposure of broiler chicks to mild stress at early age help in acquiring thermotolerance at latter age. This was first reported in rats by Levine (1962). The author discovered that mild stress at early age affects the adrenocortical functioning during adulthood.

It was later confirmed in broiler chickens (Yahav and Plavnik 1999; Zulkifli et al. 2000; Liew et al. 2003). From this assertion, there are two strategies that have been explored: thermal conditioning (TC) and early feed restriction (EFR). TC involves exposing chicks at early age post-hatch to elevated ambient temperature (Arjona et al. 1990; Yahav and Hurwitz 1996; Yahav and McMurtry 2001) within the first 6 days while EFR subjected the chicks to varying degrees of hunger during the same period (Zulkifli et al. 1994). TC has been demonstrated to be effective as a tool for thermotolerance acquisition in poultry but its application is not practicable in the traditional open-sided poultry houses common in most tropical and developing countries. The cost of heating poultry house to a desired temperature is high. Besides, the technicality associated with thermal conditioning such as length and degree of heat exposure may not be easily mastered by the local farmers. This leaves the only option for thermotolerance acquisition in the developing and underdeveloped world to application of early feed restriction.

Sublethal stress imposed by feed withdrawal in the early age post-hatch on broiler chicks has been noted to confer inherent capability in the birds to cope with stress in latter age (Liew et al. 2003). Abioja et al. (2014) have found that applying EFR to broiler chicks of $\mathrm{d} 5$ post-hatch for $24 \mathrm{~h}$ may help reduce hyperthermia that is common during heat spell in pen at market age. It is not known whether the response will be the same during transportation as in the acute heat spell. Improved thermotolerance in broiler chickens at market age will help against losses that do occur during transportation. Adopting feed restriction during early period of life in broiler chickens as a means of improving thermotolerance in broiler chickens is easier for farmers than adjusting pen temperature. Induced thermotolerance is generally referred to as the state at which an organism is transiently more resistant to killing by heat due to a short pretreatment at moderately elevated ambient temperatures. This usually takes place before the brain is fully matured for thermoregulation. During ontogeny in chicken, embryo undergoes a transition from poiklothermy to homeothermy, which is completed, at the early post-hatching. Full-blown 
homeothermy starts at approximately 10 days post-hatch. Early age thermal conditioning by exposing young chicks to $40{ }^{\circ} \mathrm{C}$ for $24 \mathrm{~h}$ reduces body temperature and improves long-term broiler resistance to HS without negative effects on growth and feed conversion ratio.

Zulkifli et al. (2000) reported that acute HS resulted in increase in heterophil/ lymphocyte ratio for all feed-restricted groups and the ad libitum group. But broilers restricted from $60 \%$ of daily feed requirement on day 4,5 , and 6 had the least heterophil/lymphocyte ratio. The authors concluded it appeared $60 \%$ feed restriction is beneficial in improving growth and survivability of female broiler chickens exposed to HS later in life. The authors restricted the feed by percentage on three consecutive days (day 4, 5, and 6). Exact feed intake of the birds may not be ascertained: feed intake depends on strain, genotype, environmental condition in the pen, body weight, etc. Farmer may have problem calculating the feed intake. Besides, percentage feed restriction may not give the exact day the EFR is most effective. Therefore it is important to determine exact day of life the chicks should be subjected to early feed restriction by farmer which ensures best acquisition of thermotolerance.

\section{Use of Honey and Other Natural Phytochemicals}

The age-long conventional use of antistress antioxidant formula containing a mixture of vitamins and minerals to help broiler chickens cope during heat spell in rearing has proved to be effective. However, the use of phytochemicals that possess or are suspected to possess efficacious antioxidant properties in the management of HS in poultry production is becoming more popular (Abioja et al. 2012). Efficacy of honey and some other naturally occurring materials from plants such as coconut water, olive leaf extract, and propolis during stressful conditions in chickens had been reported in literatures. Honey has recently been reputed as a possible natural source of antioxidant in broiler chickens (Abioja et al. 2012; Osakwe and Igwe 2015; Oke et al. 2016) with some positive results because of its phenolic and flavonoid compounds content and various phytochemicals that possess antioxidant properties. It has been used during acute heat and transportation stress conditions. Honey is effective because some of its components are substances known to have physiological actions in the body systems of animals. Diluted drinking water of concentration $20 \mathrm{ml}$ honey dissolved in a liter drinking water had positive effect on respiratory and heart rates, calcium metabolism, bone formation, and some internal organs in heat stressed broiler chickens. Honey in drinking water could be of help in improving the welfare of broiler chickens during stress episode by increasing the packed cell volume, red blood cell count, and hemoglobin concentration according to Abioja et al. (2019). It helps in protecting gastrointestinal tract, liver, kidney, pancreas, eye, plasma, red blood cells, and reproductive organs against oxidative stress in rats (Zaid et al. 2011; Erejuwa et al. 2012).

The presence of phenolic compounds and flavonoids in honey had been primarily implicated as the reason for its antioxidant activity. Phenolic compounds are good in 
free radical scavenging, hydrogen donation, singlet oxygen quenching, and metal ion chelation. Phenolics and flavonoids do help in correction of the redox perturbations in the body by counteracting the damage caused by oxidants such as oxygen, hydroxide, superoxide, and/or lipid peroxyl radicals. Exogenous nonenzymatic antioxidants in honey synergistically support the endogenous antioxidant enzymes, such as superoxide dismutase (SOD), catalase (CAT), and glutathione peroxidase (GPX), to eradicate reactive oxygen species. Honey has various antioxidant constituents that act together for the same goal but at different cellular and subcellular levels (Erejuwa et al. 2012; Oryan et al. 2016; Kamaruzzaman et al. 2019).

It contains no fat and cholesterol contents. However, the use of honey must be with caution. It was reported that there were infiltrations of fat cells in the liver tissue of albino rats fed with honey over a long period. This may result in nonalcoholic fatty liver disease or in other unpleasant conditions harmful to health if not well managed. It has been discovered that long-term administration of honey caused deformation and atrophy of specific reproductive apparatus in laying chickens. Other authors had earlier stated that chronic consumption of unprocessed Nigerian honey resulted in decreased bile flow, increased bile cholesterol, and decreased plasma cholesterol in albino rats. The fear that more cholesterol molecules especially much dreaded low-density lipoproteins may be deposited in the eggs of chickens offered honey is pervading the air. Besides, vitamin A content is important in human nutrition. Improvement in vitamin A content of eggs will go a long way in correcting its deficiency and contribute to the welfare of consumers. Millions of preschool-aged children in developing countries are suffering from vitamin A deficiency, which may lead to blindness (Underwood 1998). The deficiency of vitamin A is a public health issue that needs attention. Fortification of eggs for the children will be a welcome idea, should honey help in achieving this. By-products of honey such as honey slum gum (Babarinde et al. 2011), propolis (Chen et al. 2009), and bee pollen (Wang et al. 2005; Hašcík et al. 2012) had been used in broiler production and found to be effective.

Honey is good but must be used with caution, especially in its application in poultry production. In literature, it has been reported that there were infiltrations of fat cells in the liver tissue of rats which was dosage-dependent (Avwioro et al. 2012), decreased bile flow, increased bile cholesterol, and decreased plasma cholesterol (Alagwu et al. 2009) in Albino rats and hypertrophy of follicle, giving it a deformed shape instead of the usual round shape in laying chickens (Abioja and Adekunle 2018). The authors concluded that chronic consumption of honey may increase the risk of hepatic damage.

Naturally occurring solution found inside the fleshy eatable part of coconut called coconut water could also be used as antistress in broiler chickens during heat spells. It contains a lot of bioactive metabolites which have not been explored (Reddy and Lakshmi 2014). Preliminary studies (Abioja et al. 2015) with diluted coconut water in drinking water as a viable candidate in lowering body temperature in heat and transportation stressed broiler chickens gave a promising results. Saat et al. (2002) stated that coconut water has been used in humans after physical exercise or long journey as an ideal rehydrating and refreshing drink. Its sugar content and mineral composition (electrolytes) have been identified as reason for the usefulness. Coconut 
water stimulates higher water consumption, which ensures availability of enough water in the body to facilitate evaporative cooling (panting) under hot environmental conditions. Chickens ingest more water under HS conditions. Prades et al. (2012a, b) reviewed the uses, composition, properties, preservation, and processing of coconut water. Major constraint in the adoption of coconut water as antistress in broiler production is in quantity that would be required for a large-scale commercial broiler industry. More research works are necessary to ascertain the appropriate concentration of diluted coconut water for the chickens. However, it can be used easily in small scale, backyard, and family poultry production. Other materials that could be used in ameliorating the negative effects of HS are raffia palm wine, olive leaf extract, and orange peel extract.

\section{Breeding for Thermotolerant Strains in Africa}

Broiler chickens reared in the tropics were developed in the cooler regions of the world and introduced into the tropics. They often respond differently under the new environment, mostly growing at lower rate than in their home environment. Thus optimal poultry production in the hot regions therefore requires an adequate and appropriate management system that can reduce the effects of HS to the minimum. Olori (2008) in a review stated that to develop broiler chickens for Africa, an understanding of the factors affecting poultry production such as the climate, production systems, and available feed resources in Africa is required. One of the major constraints in broiler breeding is the fact that productivity traits are negatively correlated with thermotolerance. The available major genes (naked-neck, frizzle-feather, and dwarfism) in locally adapted breeds of chickens all over Africa must be explored. FUNAAB-alpha broiler lines were developed by Professor Olufunmilayo Adebambo and her team from several crosses and selection activities among flocks of Nigerian local chickens. The newly developed chicken lines had just been registered and tested in different agroecological zones of the Nigeria and parts of West African coast.

A recent report on the on-station performance evaluation of improved tropically adapted chicken breeds for smallholder poultry production systems in Nigeria was given by Bamidele et al. (2019). The authors in the study identified FUNAAB Alpha and Noiler as being more suitable for dual-purpose functions (egg and meat), while Sasso and Kuroiler (meat) and Shika-Brown (egg) were observed to be better suited for single purpose functions. Chickens bred taken into consideration the climate of African land should be given preference as the pangs of climate change is envisaged. Breeds like FUNAAB-alpha, Kuroiler, Noiler, Sasso, and Shika-brown chickens are now becoming popular in the hot regions of Africa.

\section{Others Adaptation Options}

Organization of enlightenment programs, workshops, and trainings for the broiler producers and stakeholders on adaptation of broiler chickens to climate change from 
time to time by governmental agencies is necessary in Africa. Awareness and advocacy about climate change should be extended to the young people and other categories of people. Sustainable Development Goals should involve younger generations of African populace in schools where they can be furnished with adequate and up-to-date information about climate change. Indigenous technical know-hows of the African peoples, in forms of herbs, extracts, and other phytochemicals should be explored in keeping broiler chickens adapted to impending global warming.

\section{Conclusion}

As the evidences of climate change are becoming more pronounced over Africa, various adaptation options available for broiler production in literatures include building housing systems that ensure climate amelioration for the birds, manipulations of feed and feeding systems, supplying adequate water of good quality, ensuring adequate stocking density, use of natural phytochemicals that ensure balanced oxidative status in the body system, and breeding for thermotolerant strains in Africa. Enlightenment programs should be organized for poultry farmers by governmental and nongovernmental agencies on the climate change mitigation, adaptation, and resilience strategies in order to improve livelihood of the people in a sustainable manner.

\section{References}

Abioja MO (2010) Temperature-humidity effects on egg fertility and evaluation of vitamin C and cold water on broiler growth in hot season. A Ph.D. thesis submitted to Department of Animal Physiology, University of Agriculture, Abeokuta, 157pp

Abioja MO, Adekunle MO (2018) Climate change: depression in Egg production in chickens during the hot season with long term honey administration. In: Leal Filho W (ed) Handbook of climate change resilience. Springer International Publishing AG, https://doi.org/10.1007/978-3319-71025-9_15-1

Abioja MO, Abiona JA, Sodipe OG, Adeleye OO, Akibo TE, Daramola JO, Oke OE, Williams TJ, Oguntuase OM, Oladapo OI, Okanlawon OR, Mudasiru AO, Siyanbola AY, Ogunduyi BO, Soyiga BM, James IJ, Osinowo OA (2015) Effect of coconut water on rectal temperature and blood glucose in broilers subjected to acute heat and transportation stress. Nig J Anim Sci 17 (2):141-147

Abioja MO, Akinjute OF, Balogun SI, Oguntimehin MS, Oluwasola TO (2019) Effect of honey on haematology, plasma biochemistry and liver enzymes in broiler chickens administered dietary corticosterone. Stress Physiol Biochem 15(3):5-13

Abioja MO, Ogundimu KB, Akibo TE, Odutola KE, Ajiboye OO, Abiona JA, Williams TJ, Oke OE, Osinowo OA (2012) Growth, mineral deposition and physiological responses of broiler chickens offered honey in drinking water during hot-dry season. Int J Zool 4:1-6

Abioja MO, Osinowo OA, Smith OF, Eruvbetine D (2013) Physiological and haematological responses of broiler chickens offered cold water and vitamin $\mathrm{C}$ during hot-dry season. Nig $\mathrm{J}$ Anim Prod 40(1):24-36

Abioja MO, Osinowo OA, Smith OF, Eruvbetine D, Abiona JA (2011) Evaluation of cold water and vitamin $C$ on broiler growth during hot-dry season in South-Western Nigeria. Archiv de Zoot 60 (232):1095-1103 
Abioja MO, Sodipe OG, Abiona JA, Oladipo KA, Kasali OD, Akerele Z, Ola A, Oke H, Ogundele $\mathrm{O}$, Osinowo OA (2014) Thermotolerance acquisition in broiler chickens through early feed restriction: response to acute heat stress. Pertanika J Trop Agric Sci 37(3):311-319

Abudabos AM, Samara EM, Hussein EOS, Al-Ghadi MQ, Al-Atiyat RM (2013) Impacts of stocking density on the performance and welfare of broiler chickens. Italian J Anim Sci 12:683-692

ACMAD (2017) The state of climate in Africa. African Center for Meteorological Application for Development. https:/www.acmad.net/new/sites/default/files/The-State-of-Climate-in-Africa2017-Report-March-2018-ACMAD.pdf. Accessed 11 Mar 2020

Ahmad T, Sarwar M (2006) Dietary electrolyte balance: implications in heat stressed broilers. Worlds Poult Sci J 62:638-653

Alagwu E, Nneli RO, Okwari OO, Osim EE (2009) Bile secretion in albino rat following chronic honey intake. Nig J Physiol Sci 24:203-206

Alemayehu A, Woldeamlak B (2017) Smallholder farmers' coping and adaptation strategies to climate change and variability in the central highlands of Ethiopia. Local Environ 22(7):825-839. https:// doi.org/10.1080/13549839.2017.1290058

Al-Saffar AA, Rose SP (2002) Ambient temperature and the egg laying characteristics of laying fowl. Worlds Poult Sci J 58(3):317-332

Altan O, Altan A, Oguz I, Pabuccuoglu A, Konyalioglu S (2000) Effects of heat stress on growth, some blood variables and lipid oxidation in broilers exposed to high temperature at an early age. Br Poult Sci 41(4):489-493

Arjona AA, Denbow DM, Weaver WD Jr (1990) Neonatally-induced thermotolerance: physiological responses. Comp Biochem Physiol 95A:393-399

Attia YA, Hassan RA, Tag El-Din AE, Abou-Shehema BM (2011) Effect of ascorbic acid or increasing metabolizable energy level with or without supplementation of some essential amino acids on productive and physiological traits of slow-growing chicks exposed to chronic heat stress. J Anim Physiol Anim Nutr 95:744-755

Avwioro GO, Onyije FM, Atoni AD, Nduku A (2012) Non-alcoholic fatty liver disease following administration of unprocessed Nigerian honey. Adv Biol Res 6:141-145

Awojobi HA, Oluwole BO, Adekunmisi AA, Buraimon RA (2009) Performance of finisher broilers fed wet mash with or without drinking water during wet season in the tropics. Int J Poult Sci 8 (6):592-594

Ayo JO, Obidi JA, Rekwot PI (2011) Effects of heat stress on the well-being, fertility and hatchability of chickens in the northern Guinea savannah zone of Nigeria: a review. ISRN Vet Sci 1-10. https://doi.org/10.5402/2011/838606

Babarinde SA, Oladunjoye IO, Ojebiyi OO, Oyedeji SA (2011) Inclusion of honey bee slum gum in broiler chicken feed. Int J Agric Biol 13(5):781-785

Bamidele O, Sonaiya EB, Adebambo OA, Dessie T (2019) On-station performance evaluation of improved tropically adapted chicken breeds for smallholder poultry production systems in Nigeria. Trop Anim Health Prod. https://doi.org/10.1007/s11250-019-02158-9

Borges SA, Fischer da Silva AV, Ariki J, Hooge DM, Cummings KR (2003) Dietary electrolyte balance for broiler chickens under moderately high ambient temperatures and relative humidities. Poult Sci 82:301-308

Bruno LDG, Maiorka A, Macari M, Furlan RL, Givisiez PEN (2011) Water intake behaviour of broiler chickens exposed to heat stress and drinking from bell or and nipple drinkers. Brazilian J Poult Sci 13(2):147-152

Calefi AS, Quinteiro-Filho WM, Ferreira AJP, Palermo-Neto J (2017) Neuroimmunomodulation and heat stress in poultry. Worlds Poult Sci J 73:493-504

Chen YJ, Huang AC, Chang HH, Liao HF, Jiang CM, Lai LY, Chan JT, Chen YY, Chiang J (2009) Caffeic acid phenethyl ester, an antioxidant from propolis, protects peripheral blood mononuclear cells of competitive cyclists against hyperthermal stress. J Food Sci 74(6):H162-H167 
Chikumba N, Chimonyo M (2014) Effects of water restriction on the growth performance, carcass characteristics and organ weights of naked neck and Ovambo chickens of southern Africa. Asian-Austral J Anim Sci 27(7):974-980

Dei H, Bumbie GZ (2011) Effect of wet feeding on growth performance of broiler chickens in a hot climate. Br Poult Sci 52(1):82-85

Erejuwa OO, Sulaiman SA, Ab Wahab MS (2012) Honey: a novel antioxidant. Molecules $17(4): 4400-4423$

FAO (2006) Food and agriculture organization of United Nations. Livestock's long shadow: environmental issues and options. http://www.fao.org/3/a0701e/a0701e.pdf. Accessed 11 Mar 2020

FAO (2020) Gateway to poultry production and products. http://www.fao.org/poultry-productionproducts/production/poultry-species/chickens/en/. Accessed 11 Mar 2020

Farghly MFA, Galal AE, Ahmad EAM (2019) Using wet feed in feeding Japanese quail under summer conditions. Egyptian Poult Sci J 39(2):391-403

Hašcík P, Elimam I, Garlík J, Kacániová M, Cubon J, Bobko M, Abdulla H (2012) Impact of beer pollen as feed supplements on the body weight of broiler Ross 308. Afr J Biotech 11(89):1559615599

Hummel D (2015) Climate change, land degradation and migration in Mali and Senegal- some policy implications. Migration and Devt 5(2):211-233

Iheukwumere FC, Herbert U (2003) Physiological responses of broiler chickens to quantitative water restrictions: haematology and serum biochemistry. Int J Poult Sci 2(2):117-119

IPCC (2007) Intergovernmental panel on climate change: AR4-the intergovernmental panel on climate change 4th assessment report. Jackson Institute, University College, London

Kamaruzzaman MA, Chin KY, Ramli ESM (2019) A review of potential beneficial effects of honey on bone health. Evid Based Complementary Altern Med 1-10. https://doi.org/10.1155/2019/ 8543618

Karaca AG, Parker HM, Yeatman JB, McDaniel CD (2002) The effects of heat stress and sperm quality classification on broiler breeder male fertility and semen ion concentrations. Br Poult Sci 43(4):621-628

Lara LJ, Rostagno MH (2013) Impact of heat stress on poultry production. Animals 3:356-369

Levine S (1962) Plasma-free corticosteroid response to electric shock in rats stimulated in infancy. Science 135:795-796

Liew PK, Zulkifli I, Hair-Bejo M, Omar AR, Israf DA (2003) Effects of early age feed restriction and heat conditioning on heat shock protein 70 expression, resistance to infectious bursal disease and growth in male broiler chickens subjected to heat stress. Poult Sci 82:1879-1885

Manning L, Chadd SA, Baines RN (2007) Water consumption in broiler chicken: a welfare indicator. Worlds Poult Sci J 63:63-71

Mitchell MA, Sandercock DA, Macleod MG, Hunter RR (2005) Thermoregulatory and metabolic heat production responses during acute heat stress in genetically improved broiler chickens. Proceedings of the international poultry scientific forum. Southern Poultry Science Society, Atlanta, p 110

Mustafa YS, Sulehria AQK, Muneer MA, Munir R (2010) Effect of water restriction on the lymphoid organs and production of broilers. Biologia 56(1\&2):63-68

Ngaira JKW (2007) Impact of climate change on agriculture in Africa by 2030. Scient Res Essays 2 (7):238-243

Niang I, Ruppel OC, Abdrabo MA, Essel A, Lennard C, Padgham J, Urquhart P (2014) In: Barros VR, Field CB, Dokken DJ, Mastrandrea MD, Mach KJ, Bilir TE, Chatterjee M, Ebi KL, Estrada YO, Genova RC, Girma B, Kissel ES, Levy AN, MacCracken S, Mastrandrea PR, White LL (eds) Climate change: Impacts, adaptation and vulnerability. Par B: regional aspects. Contribution of Working Group II to the Fifth Assessment Report of the Intergovernmental Panel on Climate Change. Cambridge University Press, Cambridge, United Kingdom and New York, pp 1199-1265

Nichelmann M, Tzschentke B (2002) Ontogeny of thermo-regulation in precocial birds. Comp Biochem Physiol 131(4):751-763 
Oke OE, Sorungbe FO, Abioja MO, Oyetunji O, Onabajo AO (2016) Effect of different levels of honey on physiological, growth and carcass traits of broiler chickens during dry season. Acta Agric Slov 108:45-53

Olori VE (2008) Breeding broilers for production systems in Africa. Nig Poult Sci J 5(4):173-180

Oryan A, Alemzadeh E, Moshiri A (2016) Biological properties and therapeutic activities of honey in wound healing: a narrative review and meta-analysis. J Tissue Viability 25(2):98-118

Osakwe I, Igwe R (2015) Physiological responses of laying birds fed honey and vitamin C in drinking water. In: A paper presented at conference on international research on food security, natural resource management and rural development, pp 1-6

Prades A, Dornier M, Diop N, Pain JP (2012a) Coconut water uses, composition and properties: a review. Fruits 67:87-107

Prades A, Dornie M, Diop N, Pain JP (2012b) Coconut water preservation and processing: a review. Fruits 67:157-171

Reddy EP, Lakshmi TM (2014) Coconut water- properties, uses, nutritional benefits in health and wealth and in health and disease: a review. J Curr Trends Clin Med Lab Biochem 2(2):6-18

Renaudeau D, Collin A, Yahav S, De Basilio V, Gourdine JL, Collier RJ (2012) Adaptation to hot climate and strategies to alleviate heat stress in livestock production. Animal 6:707-728

Rozenboim I, Tako E, Gal-Garber O, Proudman JA, Uni Z (2007) The effect of heat stress on ovarian function of laying hens. Poult Sci 86(8):1760-1765

Saat M, Singh R, Gamini Sirisinghe R, Nawawi M (2002) Rehydration after exercise with fresh young coconut water, carbohydrate electrolyte beverage and plain water. J Physiol Anthrop Appl Human Sci 21:93-104

Santos RR, Awati A, Roubos-van den Hil PJ, Tersteeg-Zijderveld MH, Koolmees PA, FinkGremmels J (2015) Quantitative histo-metric analysis of heat-stress-related damage in the small intestines of broiler chickens. Avian Pathol 44(1):19-22

Shields S, Greger M (2013) Animal welfare and food safety aspects of confining broiler chickens to cages. Animals 3:386-400

Simsek UG, Erisir M, Ciftci M, Tatli Seven P (2014) Effects of cage and flooring housing systems on fattening performance, oxidative stress and carcass defects in broiler chicken. Kafkas Üniversitesi Veteriner Fakültesi Dergisi 20(5):727-733

Syafwan S, Kwakkel RP, Verstegen MWA (2011) Heat stress and feeding strategies in meat-type chickens. Worlds Poult Sci J 67(4):653-674

Tiruneh S, Tegene F (2018) Impacts of climate change on livestock production and productivity and different adaptation strategies in Ethiopia. J Applied Adv Res 3(3):52-58

Tzschentke B (2007) Attainment of thermoregulation as affected by environmental factors. Poult Sci 86:1025-1036

Tzschentke B, Basta D (2002) Early development of neuronal hypothalamic thermosensitivity in birds: influence of epigenetic temperature adaptation. Comp Biochem Physiol 131A:825-832

Tzschentke B, Basta D, Janke O, Maier I (2004) Characteristics of early development of body functions and epigenetic adaptation to the environment in poultry: focused on development of central nervous mechanisms. Avian Poult Biol Rev 15:107-118

Underwood BA (1998) Perspectives from micronutrient malnutrition eradication programs. B World Health Organ 76: 34-37

Wang J, Jin GM, Zheng YM, Li SH, Wang H (2005) Effect of bee pollen on development of immune organ of animal. Zhongguo Zhong Yao Za Zhi 30:1532-1536

Yahav S (2000) Domestic fowl: strategies to confront environmental conditions. Avian Poult Biol Rev 11:81-95

Yahav S, Hurwitz S (1996) Induction of thermotolerance in male broiler chickens by temperature conditioning at an early age. Poult Sci 75:402-406

Yahav S, McMurtry JP (2001) Thermotolerance acquisition in broiler chickens by temperature conditioning early in life - the effect of timing and ambient temperature. Poult Sci 80:1662-1666

Yahav S, Plavnik I (1999) Effect of early-age thermal conditioning and food restriction on performance and thermotolerance of male broiler chickens. Br Poult Sci 40:120-126 
Zaid SS, Sulaiman SA, Sirajudeen KN, Othman NH (2011) The effects of Tualang honey on female reproductive organs, tibia bone and hormonal profile in ovariectomised rats-animal model for menopause. BMC Complementary Altern Med 10:82-90

Zulkifli I, Che Norma MT, Israf DA, Omar AR (2000) The effect of early age feed restriction on subsequent response to high environmental temperatures in female broiler chickens. Poult Sci 79:1401-1407

Zulkifli I, Dunnington EA, Gross WB, Siegel PB (1994) Inhibition of adrenal steroidogenesis, food restriction and acclimation to high ambient temperatures in chickens. Br Poult Sci 35:417-426

Open Access This chapter is licensed under the terms of the Creative Commons Attribution 4.0 International License (http://creativecommons.org/licenses/by/4.0/), which permits use, sharing, adaptation, distribution and reproduction in any medium or format, as long as you give appropriate credit to the original author(s) and the source, provide a link to the Creative Commons license and indicate if changes were made.

The images or other third party material in this chapter are included in the chapter's Creative Commons license, unless indicated otherwise in a credit line to the material. If material is not included in the chapter's Creative Commons license and your intended use is not permitted by statutory regulation or exceeds the permitted use, you will need to obtain permission directly from the copyright holder.

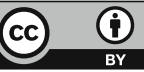

